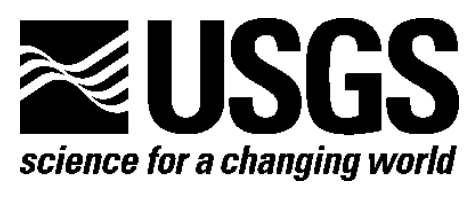

\title{
Bathymetric Map and Area/Capacity Table for Castle Lake, Washington
}

By Adam R. Mosbrucker and Kurt R. Spicer

Open-File Report 2017-1145

U.S. Department of the Interior U.S. Geological Survey 


\section{U.S. Department of the Interior \\ RYAN K. ZINKE, Secretary}

\section{U.S. Geological Survey \\ William H. Werkheiser, Acting Director}

U.S. Geological Survey, Reston, Virginia: 2017

For more information on the USGS—-the Federal source for science about the Earth, its natural and living resources, natural hazards, and the environment-visit https://www.usgs.gov/ or call 1-888-ASK-USGS (1-888-275-8747).

For an overview of USGS information products, including maps, imagery, and publications, visit https://store.usgs.gov/.

Any use of trade, firm, or product names is for descriptive purposes only and does not imply endorsement by the U.S. Government.

Although this information product, for the most part, is in the public domain, it also may contain copyrighted materials as noted in the text. Permission to reproduce copyrighted items must be secured from the copyright owner.

Suggested citation:

Mosbrucker, A.R., and Spicer, K.R., 2017, Bathymetric map and area/capacity table for Castle Lake, Washington: U.S. Geological Survey Open-File Report 2017-1145, 22 p.,

https://doi.org/10.3133/ofr20171145.

ISSN 2331-1258 (online) 


\section{Contents}

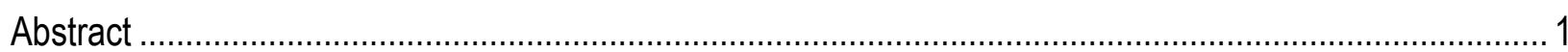

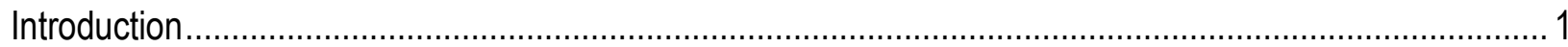

Description of Castle Lake Basin............................................................................................... 2

Monitoring, Modeling, and Mitigation.......................................................................................... 4

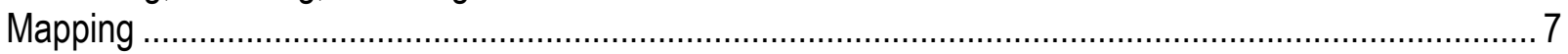

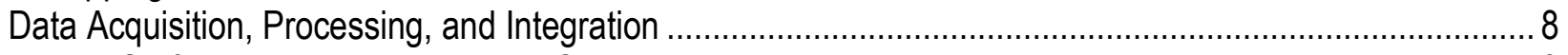

Lake Surface Elevation and Datum Conversions .......................................................................

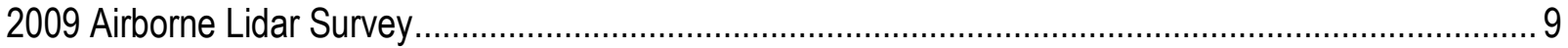

2012 Bathymetric Survey ………………............................................................................

Data Integration and Computation of Area/Capacity Table ............................................................ 13

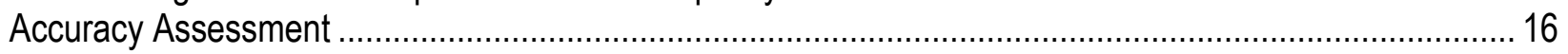

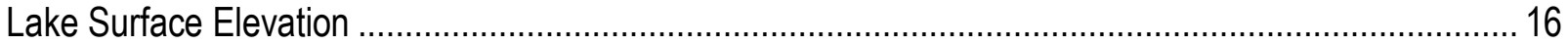

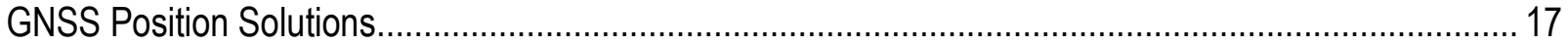

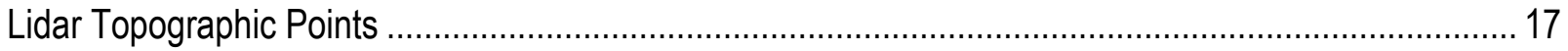

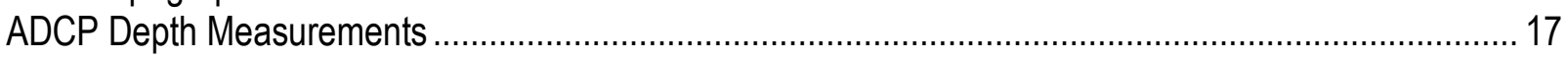

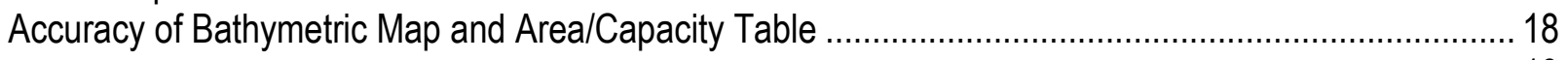

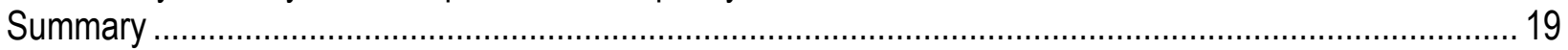

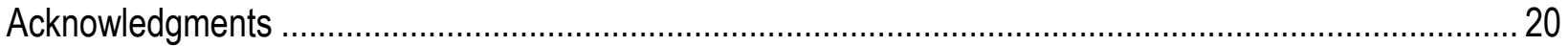

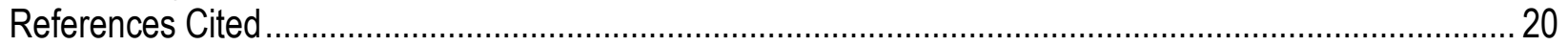

\section{Figures}

1. Map showing location of Castle Lake, Washington, and the May 18, 1980, Mount St. Helens debris avalanche .............................................................................................................. 2

2. Pre-eruption topographic map of South Fork Castle Creek and Castle Creek Marsh, Washington,

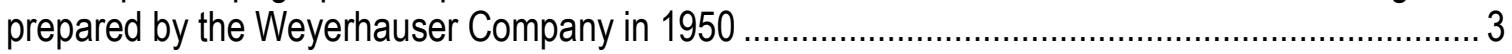

3. Photographs of Castle Lake blockage, Washington ................................................................... 4

4. Vertical aerial photographs of Castle Lake, Washington .......................................................... 5

5. Oblique aerial photograph of Castle Lake spillway, Washington ................................................... 6

6. Contour maps of Castle Lake and Castle Creek, Washington ....................................................... 8

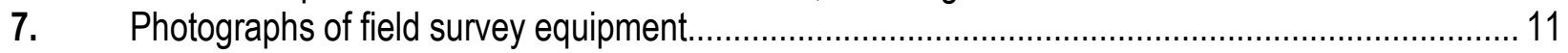

8. Map of Castle Lake, Washington, showing survey information.................................................. 12

9. Plot of calculated volume and surface area of Castle Lake, Washington ...................................... 13

10. Bathymetric map of Castle Lake, Washington ....................................................................... 15

\section{Tables}

1. Summary of physical characteristics of Castle Lake published since 1984 …............................. 7

2. Area/capacity table of Castle Lake, Washington, derived from this study................................... 14

3. Summary of estimated accuracies of each survey component.................................................. 16

4. Comparison between lake surface elevation found in this study and that published by Wiggins and others (1995) for a given lake volume. 


\section{Conversion Factors}

International System of Units to U.S. customary units

\begin{tabular}{|c|c|c|}
\hline Multiply & By & To obtain \\
\hline \multicolumn{3}{|c|}{ Length } \\
\hline centimeter $(\mathrm{cm})$ & 0.3937 & inch (in.) \\
\hline meter $(\mathrm{m})$ & 3.281 & foot $(\mathrm{ft})$ \\
\hline kilometer $(\mathrm{km})$ & 0.6214 & mile (mi) \\
\hline meter $(\mathrm{m})$ & 1.094 & yard (yd) \\
\hline \multicolumn{3}{|c|}{ Area } \\
\hline square meter $\left(\mathrm{m}^{2}\right)$ & 0.0002471 & acre \\
\hline square kilometer $\left(\mathrm{km}^{2}\right)$ & 247.1 & acre \\
\hline square meter $\left(\mathrm{m}^{2}\right)$ & 10.76 & square foot $\left(\mathrm{ft}^{2}\right)$ \\
\hline square kilometer $\left(\mathrm{km}^{2}\right)$ & 0.3861 & square mile $\left(\mathrm{mi}^{2}\right)$ \\
\hline \multicolumn{3}{|c|}{ Volume } \\
\hline cubic meter $\left(\mathrm{m}^{3}\right)$ & 0.0002642 & million gallons (Mgal) \\
\hline cubic meter $\left(\mathrm{m}^{3}\right)$ & 35.31 & cubic foot $\left(\mathrm{ft}^{3}\right)$ \\
\hline cubic meter $\left(\mathrm{m}^{3}\right)$ & 1.308 & cubic yard $\left(\mathrm{yd}^{3}\right)$ \\
\hline cubic kilometer $\left(\mathrm{km}^{3}\right)$ & 0.2399 & cubic mile $\left(\mathrm{mi}^{3}\right)$ \\
\hline cubic meter $\left(\mathrm{m}^{3}\right)$ & 0.0008107 & acre-foot (acre-ft) \\
\hline \multicolumn{3}{|c|}{ Flow rate } \\
\hline cubic meter per second $\left(\mathrm{m}^{3} / \mathrm{s}\right)$ & 70.07 & acre-foot per day (acre-ft/d) \\
\hline cubic meter per second $\left(\mathrm{m}^{3} / \mathrm{s}\right)$ & 35.31 & cubic foot per second $\left(\mathrm{ft}^{3} / \mathrm{s}\right)$ \\
\hline cubic meter per second $\left(\mathrm{m}^{3} / \mathrm{s}\right)$ & 22.83 & million gallons per day (Mgal/d) \\
\hline
\end{tabular}

Temperature in degrees Celsius $\left({ }^{\circ} \mathrm{C}\right)$ may be converted to degrees Fahrenheit $\left({ }^{\circ} \mathrm{F}\right)$ as ${ }^{\circ} \mathrm{F}=\left(1.8 \times{ }^{\circ} \mathrm{C}\right)+32$.

\section{Datums}

Vertical and horizontal coordinate information is referenced to multiple datums, which are discussed within the report. Elevation, as used in this report, refers to distance above the vertical datum. 


\title{
Bathymetric Map and Area/Capacity Table for Castle Lake, Washington
}

\author{
By Adam R. Mosbrucker and Kurt R. Spicer
}

\begin{abstract}
The May 18, 1980, eruption of Mount St. Helens produced a 2.5-cubic-kilometer debris avalanche that dammed South Fork Castle Creek, causing Castle Lake to form behind a 20meter-tall blockage. Risk of a catastrophic breach of the newly impounded lake led to outlet channel stabilization work, aggressive monitoring programs, mapping efforts, and blockage stability studies. Despite relatively large uncertainty, early mapping efforts adequately supported several lake breakout models, but have limited applicability to current lake monitoring and hazard assessment. Here, we present the results of a bathymetric survey conducted in August 2012 with the purpose of (1) verifying previous volume estimates, (2) computing an area/capacity table, and (3) producing a bathymetric map. Our survey found seasonal lake volume ranges between 21.0 and 22.6 million cubic meters with a fundamental vertical accuracy representing 0.88 million cubic meters. Lake surface area ranges between 1.13 and 1.16 square kilometers. Relationships developed by our results allow the computation of lake volume from near real-time lake elevation measurements or from remotely sensed imagery.
\end{abstract}

\section{Introduction}

The eruption of Mount St. Helens on May 18, 1980, in southwest Washington State consisted of a 2.5-cubic kilometer $\left(\mathrm{km}^{3}\right)$ debris avalanche followed by a lateral blast that devastated about 600 square kilometers $\left(\mathrm{km}^{2}\right)$ of forested terrain, pyroclastic flows, lahars, and tephra falls (Lipman and Millineaux, 1981). The debris avalanche deposit dammed South Fork Castle Creek, causing Castle Lake to form behind the blockage (fig. 1). Coldwater Lake (4 km north of Castle Lake) also formed on the margin of the 1980 debris avalanche deposit. Almost immediately after the 1980 eruption, the U.S. Geological Survey (USGS), U.S. Army Corps of Engineers (USACE), and U.S. Forest Service (USFS) began studies to evaluate the risk of Castle Lake catastrophically breaching the unconsolidated blockage. Comprehensive monitoring programs supported these studies until the construction of an emergency spillway in late 1980 to stabilize lake-surface elevation. Although the blockage is tall enough to safely retain the lake, it remains marginally stable and potentially susceptible to modes of failure other than overtopping under certain conditions (for example, extreme hydrologic event or large earthquake) (McKnight and others, 1984; Meyer and others, 1985; USACE, 1988, 1990, 1992; Roeloffs, 1994).

Mapping efforts over the past three decades have been scrutinized owing to uncertainties associated with horizontal and vertical geodetic control. Numerical dam-break models were used to evaluate potential flood impact downstream of the lake using volume estimated from bathymetry mapped in 1981 and published by Embrey and Dion (1988) and Roeloffs (1994). A 
lake capacity (volume) table derived from these contours (Wiggins and others, 1995) was later found to be unreliable (Wiggins and others, 1996) owing to datum uncertainty. Although these early mapping efforts adequately estimated volume for flood modeling purposes, there is limited applicability to current lake monitoring and hazard assessment.

In this paper, we provide a synopsis of past mapping efforts at Castle Lake and present the results of a recent bathymetric survey of the lake. Data from survey-grade global navigation satellite system (GNSS), multibeam hydroacoustic, and airborne light detection and ranging (lidar) provide (1) a conversion between historical datums and modern orthometric height, (2) an area/capacity table for the full range of observed lake surface elevation, and (3) a bathymetric map of Castle Lake. Lastly, we assess the accuracy of our data and compare our survey results to volume estimates previously used in dam-break flood models. Relationships developed by our results allow the computation of lake volume from near real-time lake elevation measurements or from remotely sensed imagery.

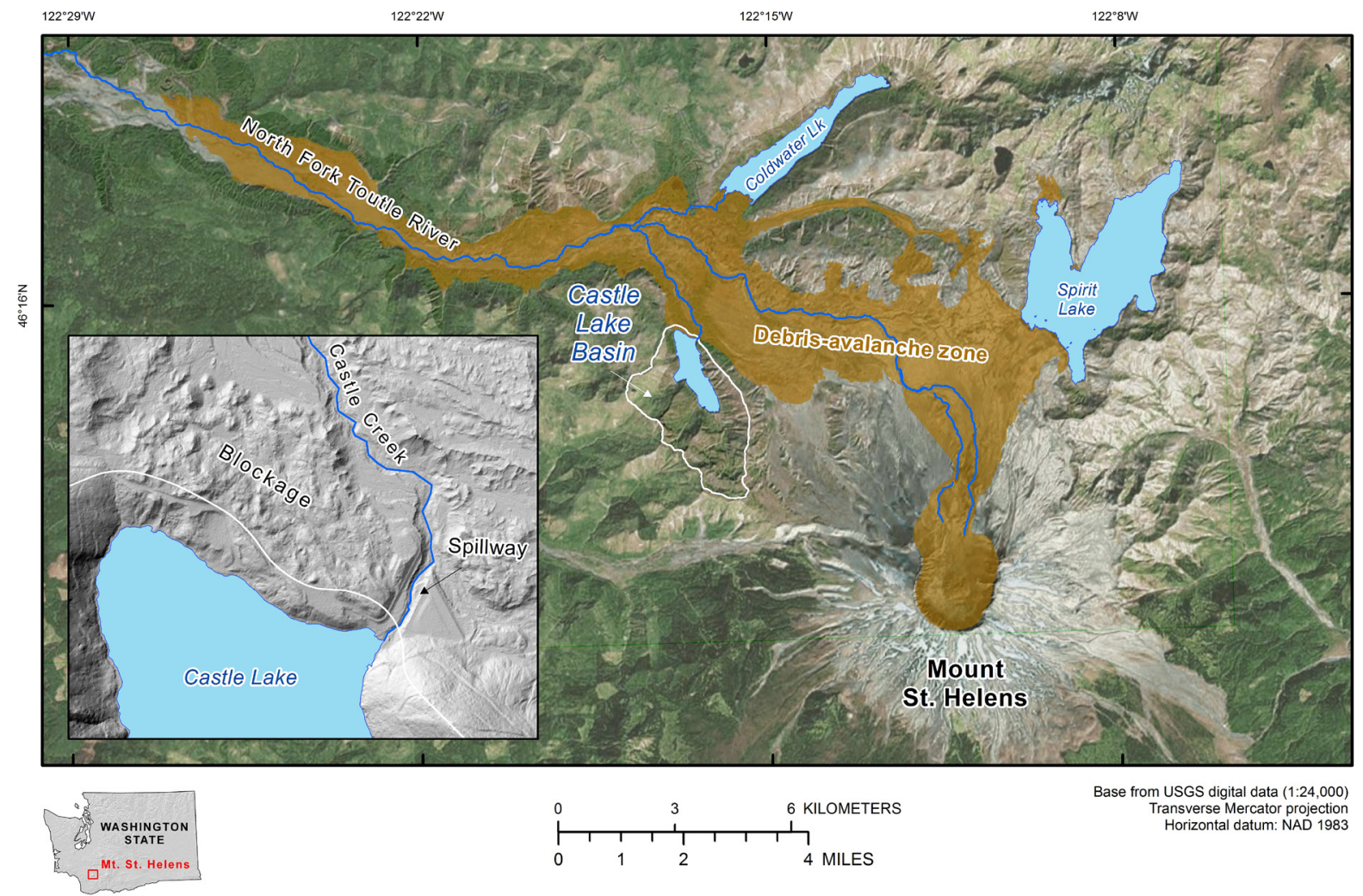

Figure 1. Map showing location of Castle Lake, Washington, and the May 18, 1980, Mount St. Helens debris avalanche, modified from plate 1 of Lipman and Mullineaux (1981). Lk, Lake.

\section{Description of Castle Lake Basin}

Castle Lake is a small sub-alpine lake located 9 kilometers $(\mathrm{km})$ northwest of Mount St. Helens. The lake is bound by steep bedrock ridges consisting of andesitic and dacitic volcanic rocks, with an $8.0-\mathrm{km}^{2}$ drainage area. Prior to the May 18, 1980, eruption, South Fork Castle Creek flowed northwest from the upper basin, across a flat alluvium-filled area known as Castle Creek Marsh, and into a 40-meter (m) deep channel incised into unconsolidated volcaniclastic deposits from Mount St. Helens that are more than 2,500 years old (fig. 2). Based on lithology, Meyer and others (1985) hypothesized that a prehistoric lake had been impounded behind thick 
pyroclastic flows or lahars from Mount St. Helens in the area of Castle Creek Marsh; this lake probably overtopped this prehistoric blockage, incising the pre-1980 South Fork Castle Creek channel.

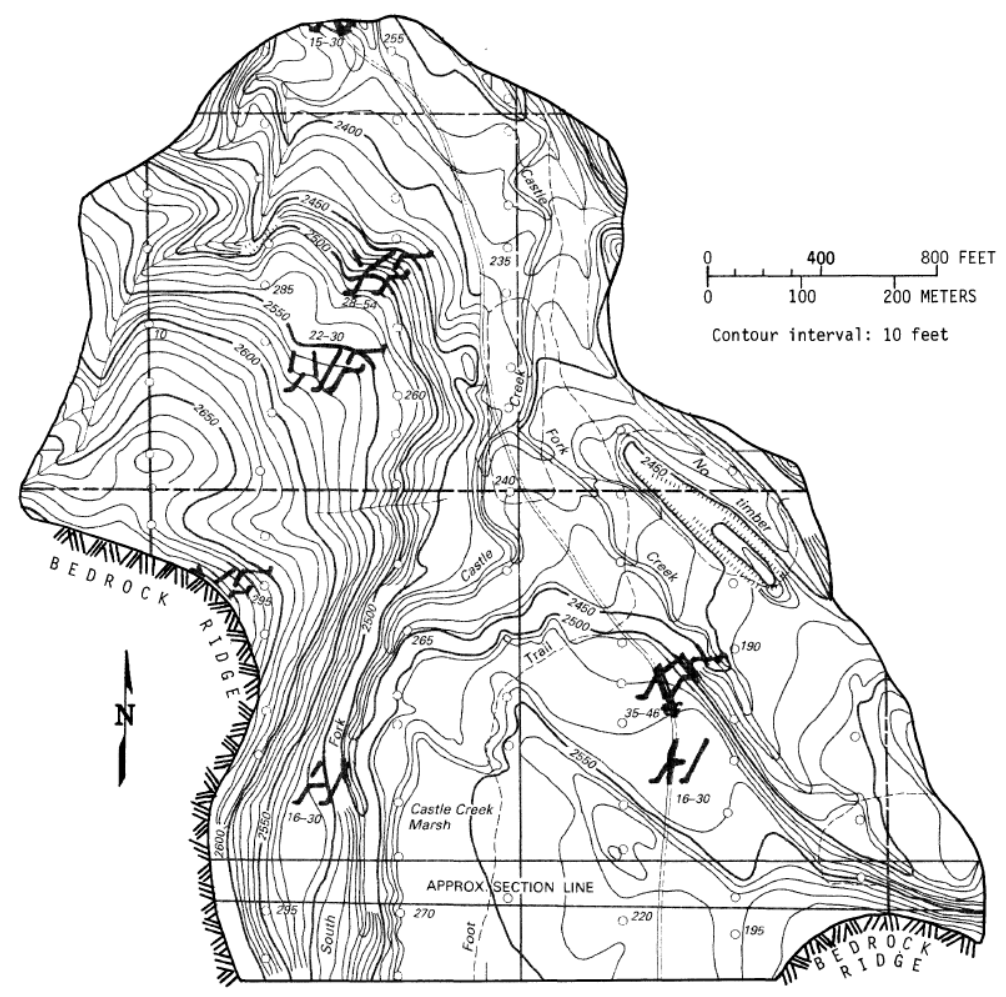

Figure 2. Pre-eruption topographic map of South Fork Castle Creek and Castle Creek Marsh, Washington, prepared by the Weyerhauser Company in 1950 (from Meyer and others, 1985).

The 1980 debris avalanche blocked South Fork Castle Creek at its junction with Castle Creek, impounding water to form present-day Castle Lake (fig. 3). The eruption deposited ash and left blown down trees on the hillslopes above the lake (USACE, 1988). Resting on top of remnants of the prehistoric blockage, the current blockage is $610 \mathrm{~m}$ long with an average width of $430 \mathrm{~m}$ (Meyer and others, 1985; USACE, 1992). Vertical distance from the crest to the lake averages $20 \mathrm{~m}$; from the crest to the downstream toe is as much as $60 \mathrm{~m}$. Blockage lithology and physical material properties are discussed in Meyer and others (1985). 


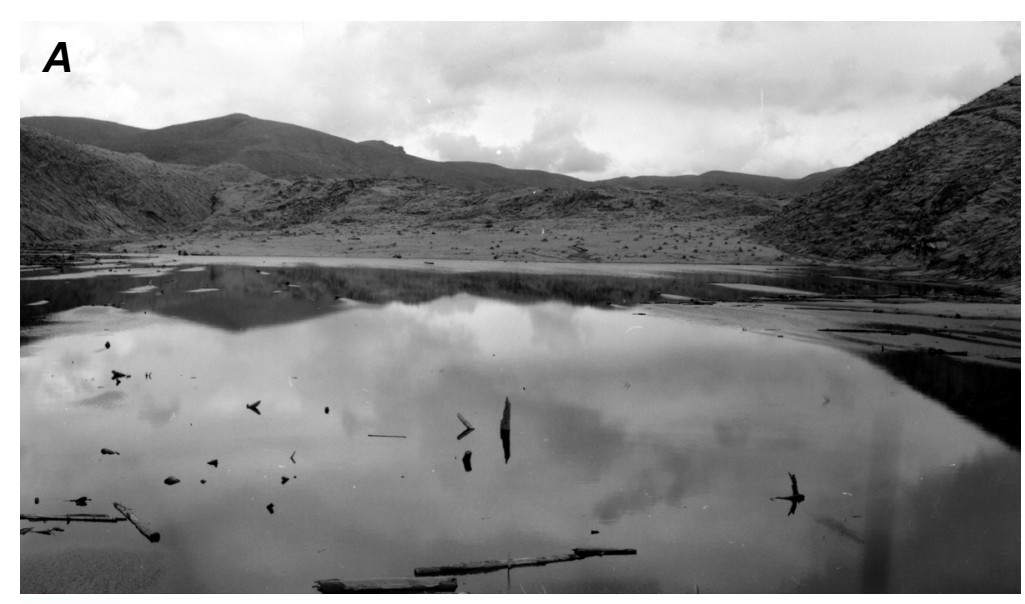

B

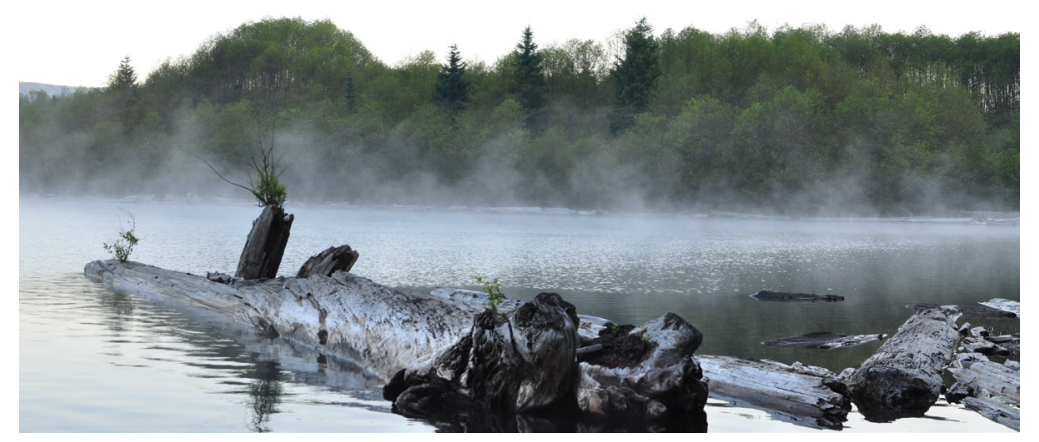

Figure 3. Photographs of Castle Lake blockage, Washington, taken A, June 11, 1980 (USGS, 1980), and $B$, August 3, 2012; view is to the northwest.

\section{Monitoring, Modeling, and Mitigation}

Numerical modeling of blockage stability and dam-break flood scenarios requires detailed geotechnical and hydrologic information. Because of concern about the potential for a catastrophic lake breakout at Castle Lake, aggressive monitoring programs began immediately after the eruption in summer 1980. The USACE, USGS, and USFS monitoring included lake surface elevation, lake volume, and blockage stability.

Lake surface elevation (or stage) and volume were monitored by aerial photography (fig. 4) and, beginning in November 1981, by several monitoring stations (or gages) (Meyer and Sabol, 1989). As many as three gages were operated at varying times; these include the original gage located on the blockage just west of the outlet channel (discontinued in 1988), a gage located near the west end of the blockage (discontinued after 1994), and the current USGS station 14240446 Castle Lake near Mount St. Helens, Washington, located on the eastern shoreline. Monitoring instrumentation at the current station includes a pressure transducer, data logger, and radio telemetry system. With a $>20$-year period of record, lake surface elevation varies by $1.6 \mathrm{~m}$ at the current gage (USGS, 2013). 

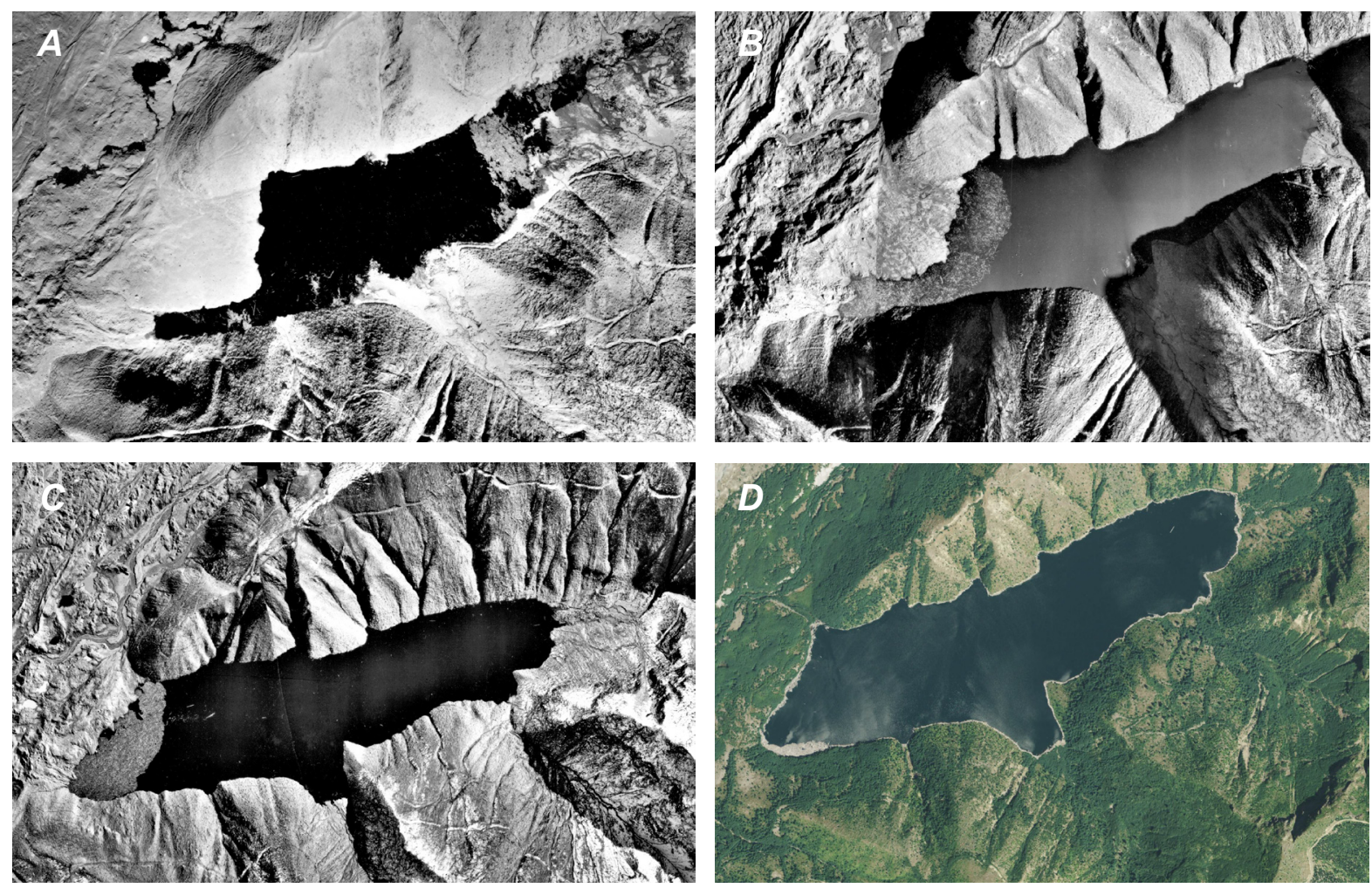

Figure 4. Vertical aerial photographs of Castle Lake, Washington, taken on $A$, July 20, 1980, $B$, November 11, 1980, C, March 1, 1981 (A-C modified from McKnight and others, 1984); and D, August 3 , 2009 (U.S. Department of Agriculture, 2011).

Based on aerial photographs, Castle Lake volume increased rapidly during the winter of 1980-1981, from $1.4 \times 10^{6}$ to $18.5 \times 10^{6}$ cubic meters $\left(\mathrm{m}^{3}\right)$ (McKnight and others, 1984). Early analysis by the USACE predicted the lake would overtop the blockage as early as spring 1982 (USACE, 1988). Based on additional monitoring data collected through the summer of 1981, the USGS projected the lake would overtop the blockage several months earlier, prompting the USACE to construct an emergency spillway in October 1981 to stabilize lake surface elevation at a volume of $22.8 \times 10^{6} \mathrm{~m}^{3}$ (Meyer and others, 1985; USACE, 1990). The spillway is $270 \mathrm{~m}$ long and $30 \mathrm{~m}$ wide (fig. 5). Its banks are reinforced with riprap whereas its bed is not; the channel is designed to be down cut by about $5 \mathrm{~m}$, effectively reducing surface elevation and volume (and thus risk) over time (USACE, 1988; USACE, 1992). Since construction was completed in 1981, the outlet has experienced about 1-3 m of incision (Mosbrucker and others, 2015), primarily occurring during large runoff events. Current elevation of the spillway crest is about $786 \mathrm{~m}$ above the North American Vertical Datum of 1988 (NAVD 88). During construction of the spillway, the lake surface was cleared of blown down trees to prevent blocking the spillway (USACE, 1988), but a substantial amount of large wood has accumulated at the outlet over the past three decades. 


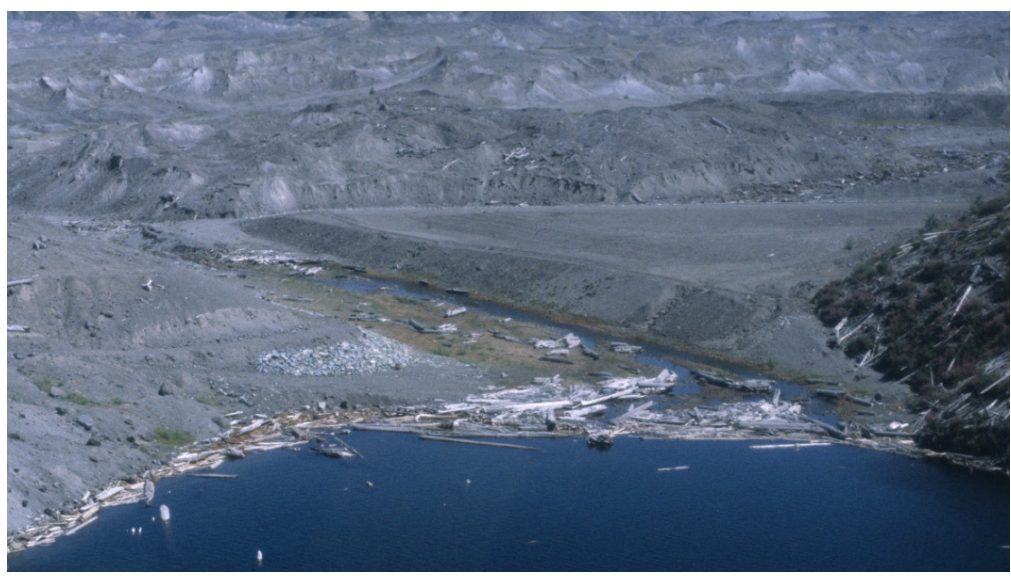

Figure 5. Oblique aerial photograph of Castle Lake spillway, Washington; view is to the north (USGS photo taken August 15, 1985).

Stability of the blockage and adjacent Castle Creek channel (fig. 1) were monitored by aerial photogrammetry, geotechnical surveys, piezometers, inclinometers (USACE, 1988, 1992; Roeloffs, 1994), and channel cross-section surveys (Mosbrucker and others, 2015). Monitoring data allowed the stability of the blockage to be evaluated using numerical groundwater models. Studies conducted between 1983 and 1994 by the USGS, USACE, Weyerhaeuser Lumber Company, and the Federal Emergency Management Agency (FEMA) concluded that although the blockage is tall enough to safely retain the lake, it is only marginally stable and potentially susceptible to modes of failure (for example, erosion, piping, liquefaction) other than overtopping under certain conditions (for example, severe hydrologic event, seasonally high ground water levels, modest earthquake activity) (McKnight and others, 1984; Meyer and others, 1985; USACE, 1988, 1990, 1992; Roeloffs, 1994).

Numerical dambreak models were used to evaluate flood impact downstream of the lake. Initial volume used in all flow simulations was $23 \times 10^{6} \mathrm{~m}^{3}$ (table 1). A full breach was modeled to produce a hyperconcentrated flood with a peak discharge between 11,000 and 40,000 cubic meters per second $\left(\mathrm{m}^{3} / \mathrm{s}\right)$, transporting a total of $4.6 \times 10^{6}$ to $107.3 \times 10^{6} \mathrm{~m}^{3}$ of entrained sediment (Laenen and Orzol, 1987; USACE, 1990; Denlinger, 2012). A recent reanalysis conducted by Denlinger (2012), prompted by continued excess sediment in the North Fork Toutle River basin and resulting mitigation work to the sediment retention structure (SRS), predicted that flow rate from a full breach (with a total volume of $56 \times 10^{6} \mathrm{~m}^{3}$ of water and sediment) will attenuate from 40,000 to $6,000 \mathrm{~m}^{3} / \mathrm{s}$ before reaching the SRS (30 km downstream of the lake), which would likely result in moderate to extreme flooding at the downstream communities of Kid Valley, Toutle, Castle Rock, Kelso, and Longview, Washington (Laenen and Orzol, 1987). 
Table 1. Summary of physical characteristics of Castle Lake published since 1984.

[m, meter; $\mathrm{m}^{3}$, cubic meter; $\mathrm{km}^{2}$, square kilometer; NA, not available; USACE, U.S. Army Corps of Engineers; USGS, U.S. Geological Survey]

\begin{tabular}{lccccl}
\hline \multicolumn{1}{c}{ Date } & $\begin{array}{c}\text { Volume } \\
\left(\mathbf{1 0}^{6} \mathbf{~}^{3}\right)\end{array}$ & $\begin{array}{c}\text { Surface area } \\
\left(\mathbf{k m}^{2}\right)\end{array}$ & $\begin{array}{c}\text { Depth, mean } \\
(\mathbf{m})\end{array}$ & $\begin{array}{c}\text { Depth, max } \\
(\mathbf{m})\end{array}$ & \multicolumn{1}{c}{ Reference } \\
\hline September 30, 1980 & 1.4 & NA & NA & NA & McKnight and others, 1984 \\
May 27, 1981 & 18.45 & NA & NA & NA & McKnight and others, 1984 \\
May 1981-August 1982 & 23 & 1.9 & 10 & $30-37$ & Embrey and Dion, 1988 \\
October 1981 & 23 & NA & NA & NA & USACE, 1990 \\
Post-spillway (>1981) & 22.8 & NA & NA & 34 & USACE, 1990 \\
September 1983 & 23 & 1.9 & 30 & NA & Meyer and others, 1985 \\
1987 & 23.1 & 1.2 & 20 & NA & Laenen and Orzol, 1987 \\
January 1992 & 23 & 1.9 & 30 & NA & USACE, 1992 \\
October 1993- & $22.8-23.5$ & NA & NA & NA & Wiggins and others, 1995 \\
September 1994 & 23 & NA & NA & NA & Roeloffs, 1994 \\
1994 & 23 & NA & NA & NA & Denlinger, 2012 \\
2012 & $21.0-22.6^{\mathrm{a}}$ & $1.13-1.16$ & 18.9 & $29.78^{\mathrm{b}}$ & This report \\
August 2012 & & & & & \\
\hline
\end{tabular}

${ }^{a} \pm 0.9$

${ }^{\mathrm{b}}$ Measured depth; actual depth may be deeper.

\section{Mapping}

Topographic and geologic mapping over the past three decades has primarily focused on the blockage rather than the lake itself. The geologic surface of the blockage was mapped in 1982-1983 (Meyer and others, 1985; USACE, 1992). Topographic mapping of the area was accomplished using aerial photogrammetry techniques prior to 2003, and commercial lidar techniques have been employed since then. A 1981 contour map, prepared by Tallany, Van Kuren, Gertis, and Thielman (TVGT) under contract with the USGS, was subject to a high degree of uncertainty owing to a problem with the horizontal control (Meyer and others, 1985). The map was referenced to an arbitrary local elevation datum, which the USGS adjusted by approximately $5.8 \mathrm{~m}$ to a geodetic elevation datum in 1983 (USACE, 1992). Land surveys conducted in 1989 and 1991 established reference monuments and provided control for contour mapping based on 1989 and 1991 aerial photographs (USACE, 1992; Roeloffs, 1994).

A bathymetric contour map of Castle Lake after the construction of the outlet channel in 1981 accompanied water chemistry data in Embrey and Dion (1988) (fig. 6A). Post-eruption topography (mapped in 1989) integrated with bathymetry (mapped in 1981) was published in Roeloffs (1994) (fig. 6B). These bathymetric contours were used to develop the lake capacity table published in the USGS Water-Data Report for water year 1994 (Wiggins and others, 1995), which Wiggins and others (1996) found to be unreliable owing to vertical datum uncertainty. 

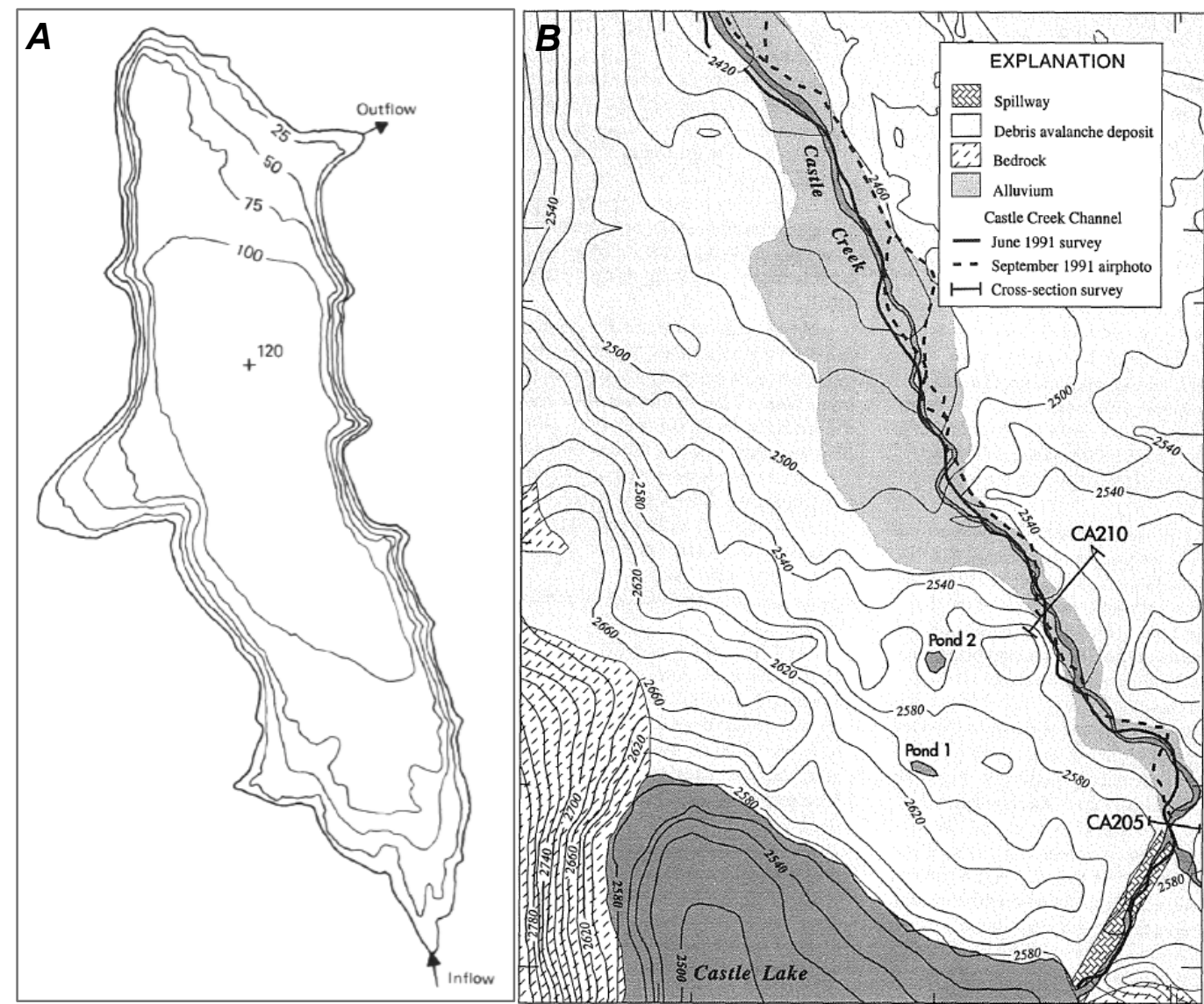

Figure 6. Contour maps of Castle Lake and Castle Creek, Washington. A, Bathymetry mapped after the construction of the outlet channel in 1981 (modified from Embrey and Dion, 1988). B, Post-eruption topography, as mapped by the USACE using 1989 aerial photogrammetry, integrated with 1981 bathymetry (modified from Roeloffs, 1994). Roeloffs (1994) notes a higher degree of uncertainty within the bathymetric contours than the topographic contours.

Mapping blockage thickness and shape was accomplished by comparing pre- and posteruption topographic maps. In 1982 and 1990, the USACE calculated blockage thickness using pre- (1938 and 1950) and post-eruption (1981 and 1989) topographic maps (USACE, 1992). Using more accurate 1978 aerial photographs, Roeloffs (1994) found the 1990 USACE values and the pre-eruption topography assumed by Meyer and Sabol (1989) and Meyer and others (1994) to be reasonable. Vertical thickness was determined to be as much as $79 \mathrm{~m}$ above the former South Fork Castle Creek channel and as little as $6 \mathrm{~m}$ near the current outlet channel (USACE, 1992; Roeloffs, 1994).

\section{Data Acquisition, Processing, and Integration}

In this study, we integrate lake surface elevation, airborne lidar, and bathymetric survey data in order to produce a bathymetric map and develop relationships between water surface elevation, volume, and surface area of Castle Lake. This section describes the acquisition and processing of each dataset. Integration requires the establishment of common datums among source data. Modern geodetic datums derived from GNSS solutions are used, rather than arbitrary local or historical geodetic datums. Horizontal coordinates are referenced to the North 
American Datum of 1983 (NAD 83) with corresponding vertical coordinates referenced to NAVD 88. Geoid model GEOID03 (National Geodetic Survey [NGS], 2011) is used to convert ellipsoid to orthometric heights, or elevations above NAVD 88. A seamless digital terrain model (DTM) is generated within a geographic information system (GIS), which provides computation of lake volume and surface area for the full range of elevation.

\section{Lake Surface Elevation and Datum Conversions}

Lake surface elevation at the Castle Lake gage (14240446) has been published in units of feet above two different datums. Prior to 1982, water surface elevation was referenced to the TVGT datum of 1981, an arbitrary local datum established by third-order reference marks surveyed in 1.6-km (1-mile) intervals by TVGT as well as auxiliary control points $( \pm 1 \mathrm{~m})$ surveyed by SPAN International, Inc. A third-order differential leveling circuit conducted by the USGS in 1991 tied gage datum to the National Geodetic Vertical Datum of 1929 (NGVD29) using two reference monuments established by the USACE in 1989 (CLM-6 and CLM-7; figs. $7 B, C$ and 8). The relative stability of these reference marks was confirmed in 1995 and 2012. In 2012, we computed a Level I GNSS network solution (as defined by Rydlund and Densmore, 2012), which tied gage datum to NAVD 88, derived using the geoid model GEOID12A (NGS, 2012a). Based on these surveys, the elevation of the TGVT datum of 1981 is $0.866 \mathrm{~m}$ (2.84 feet) lower than NGVD29 and $1.43 \mathrm{~m}$ (4.68 feet) lower than NAVD 88 (by GEOID12A) at Castle Lake. Lake surface elevation above NAVD 88 using GEOID12A was then converted to the GEOID03 model using NGS software (NGS, 2012b) in order to match the 2009 lidar survey. Mean lake surface elevation recorded at the gage during the August 2012 bathymetric survey was $786.273 \mathrm{~m}$ above NAVD 88 (by GEOID03), only 3.4 centimeters (cm) lower than the 2009 airborne lidar survey.

\section{Airborne Lidar Survey}

As part of their long-term sediment monitoring program, the USACE contracted with Watershed Sciences, Inc. to collect $214 \mathrm{~km}^{2}$ of high-precision airborne lidar data in the North Fork Toutle River basin, including Castle Lake. Data were acquired September 16-20, 2009. Mosbrucker (2014) generated a hydro-flattened DTM from laser last-return points (classified as bare earth) points. Lidar source data averaged 1.9 measurements per square meter in the Castle Lake basin. These measurement points were referenced to NAD83, with elevations above NAVD 88 (by GEOID03). Mean lake elevation during the 2009 lidar survey was $786.307 \mathrm{~m}$.

\section{Bathymetric Survey}

Bathymetry of Castle Lake was surveyed August 1-3, 2012, using methods similar to Czuba and others (2012). We made water-depth measurements with a 1,200 kilohertz (kHz) acoustic Doppler current profiler (ADCP) positioned by real-time kinematic (RTK) GNSS (hereafter referred to as RTK-GNSS) solutions. The survey-grade RTK-GNSS system consisted of a mobile receiver (the rover) mounted directly above the ADCP and two stationary receivers (base stations) (figs. 7A, $D$ and 8). A data radio transmitted real-time corrections to the rover from the main base station at the gage (fig. 8). All RTK-GNSS data were collected using the World Geodetic System of 1984 (WGS84) ellipsoid reference frame. A series of datum transformations and adjustments, outlined below, assigned position information from the rover to individual depth measurements. 
- A network solution for the base stations was computed using NGS OPUS-Projects software (NGS, 2012c). More than 700,000 observations from both base stations and five Continuously Operating Reference Stations (CORS) provided coordinates in the NAD83 (2011; epoch 2010.0000) reference frame and elevations above the NAVD 88 datum (by GEOID12A), which were later converted to the GEOID03 model.

- Rover solutions were projected into Universal Transverse Mercator (UTM) coordinates and adjusted to the base station network solution. All subsequent processing was performed in UTM Zone 10 North coordinates referenced to NAD 83 and NAVD 88 (by GEOID03). Elevation values were adjusted from the GNSS rover antenna phase center to the water surface and ADCP beam center (Teledyne RD Instruments, 2007).

- The ADCP uses four transducers arranged in a Janus configuration, with individual beams oriented at $20^{\circ}$ from the vertical (Teledyne RD Instruments, 2007). Horizontal and vertical coordinates for each water-depth measurement were provided by the RTK-GNSS system and 2-hertz $(\mathrm{Hz})$ pitch/roll sensors inside the ADCP. These data were merged in hydrographic software and exported for subsequent processing. ADCP yaw, or grid bearing, was computed from 54,000 1-Hz RTK-GNSS solutions in a GIS environment.

- Water-depth measurements from each of four transducers were corrected for instrument roll, pitch, yaw, and slope distance using a series of nested trigonometric functions to produce 216,000 lake-bed elevation points in meters. Water-depth measurements were not corrected for temperature variation owing to a complex spatial distribution. 

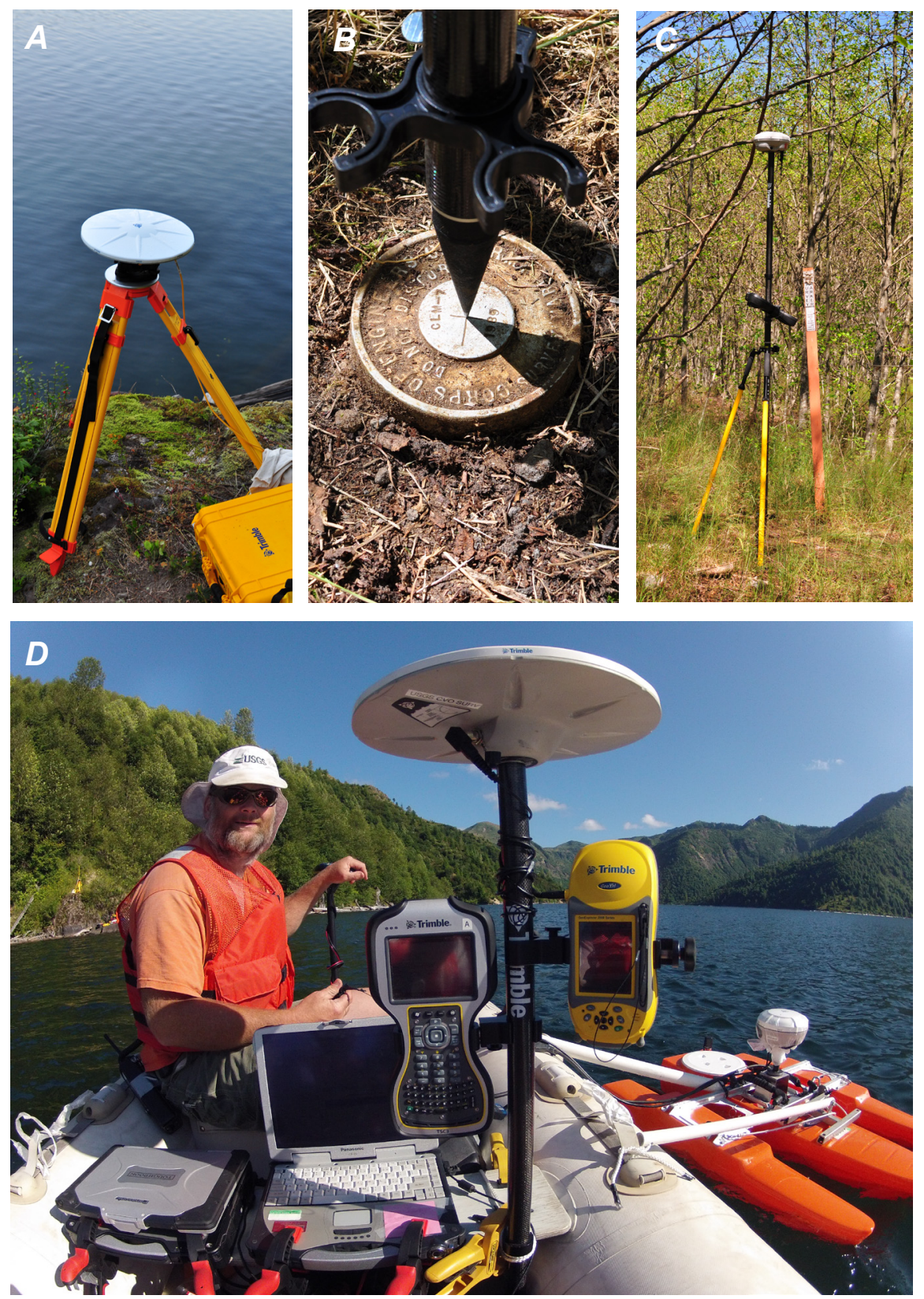

Figure 7. Photographs of field survey equipment. $A$, The primary global navigation satellite system (GNSS) base station. $B, C L M-7$ control monument. $C$, GNSS rover positioned over a control monument on the blockage. $D$, Wide-angle view from inside the survey boat showing mobile computers, GNSS equipment, and the acoustic Doppler current profiler (ADCP) positioned off the port side. 


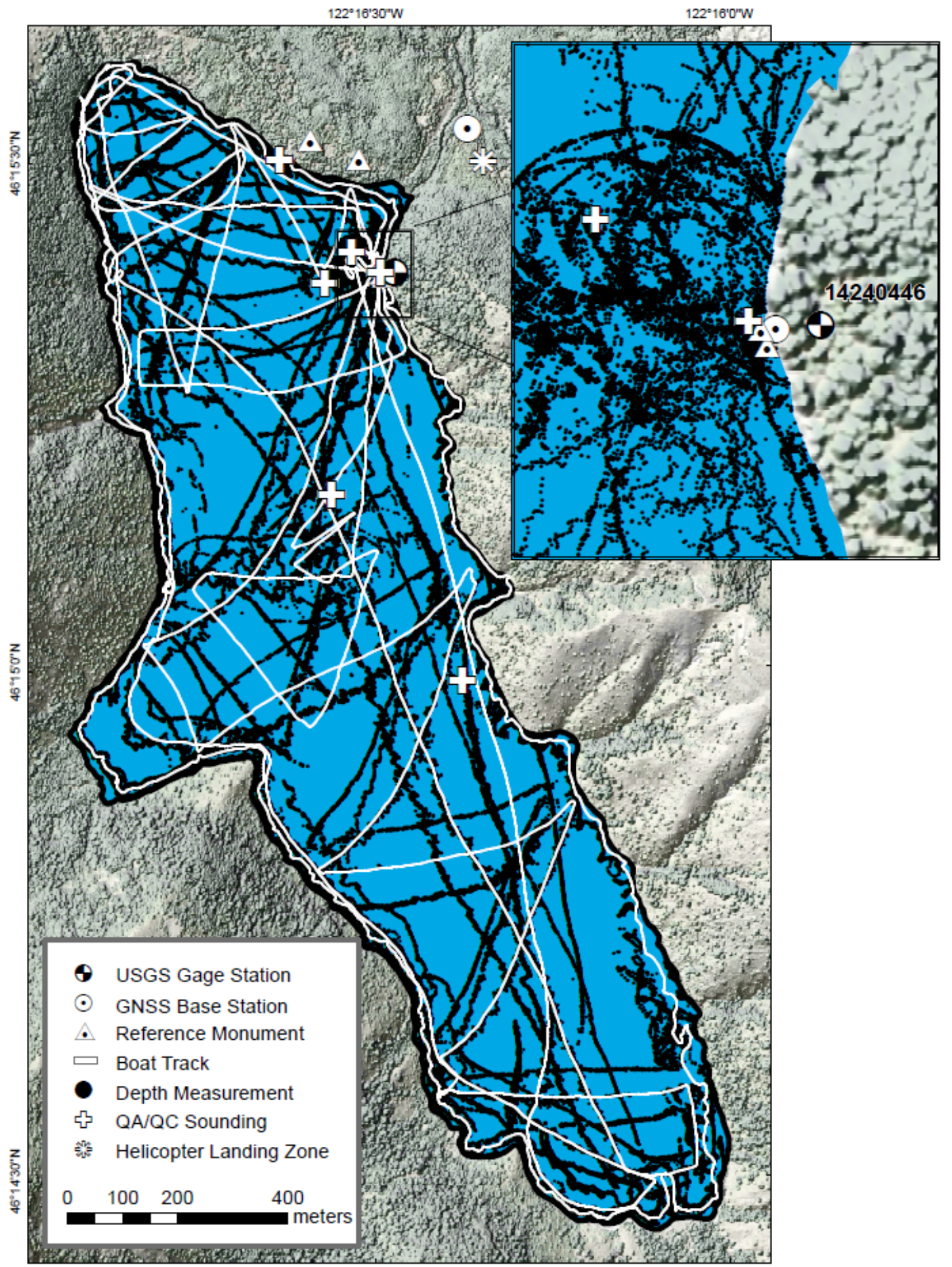

Figure 8. Map of Castle Lake, Washington, showing locations of discrete bathymetric depth measurements from four beams along a $27-\mathrm{km}$-long boat track, U.S. Geological Survey gage station, GNSS base stations, reference monuments, and quality assurance/quality control (QA/QC) points. Base map is modified from Mosbrucker (2014). 


\section{Data Integration and Computation of Area/Capacity Table}

A surface model of the Castle Lake basin was derived from georeferenced threedimensional (3D) bathymetric and lidar-derived topographic survey points. Points were imported into a GIS to generate a vector-based DTM using Delaunay triangulation (for example, Li and others, 2005; Mosbrucker and others, 2016) to generate a continuous surface of non-overlapping triangular faces. This DTM was then filtered to remove returns caused by submerged logs and smooth the transition near the shoreline before generating a final terrain model, referred to as the "final DTM" for the remainder of this report. Using a flat-water model, lake volume and surface area were calculated from the final DTM at 1-m elevation intervals between $785 \mathrm{~m}$ (below period-of-record minimum lake elevation) and $790 \mathrm{~m}$ (point at which the spillway channel is bankfull), at the mean value during the 2012 survey, and at gage record minimum and maximum values $(n=9)$. We used least-squares polynomial regression to compute lake capacity $\left(\mathrm{R}^{2}=1.000\right)$ and surface area $\left(\mathrm{R}^{2}=0.999\right)$ from continuous lake surface elevation measurements (fig. 9 and table 2). Finally, a bathymetric contour map was produced from a cartographically smoothed version of the final DTM using regularized spline interpolation (fig. 10).

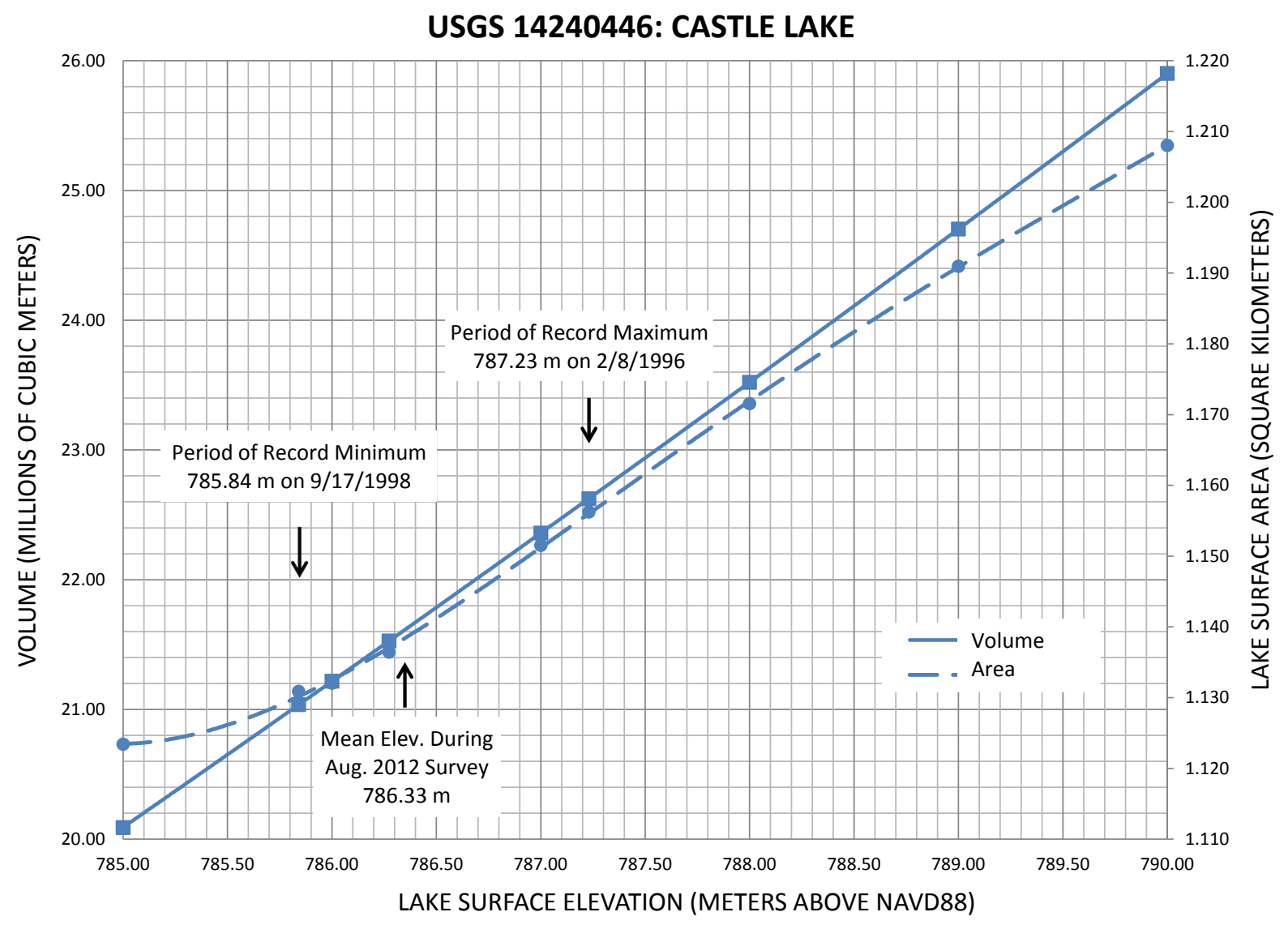

Figure 9. Plot of calculated volume and surface area of Castle Lake, Washington, from surface elevation regression equations. Surface elevation measured at USGS 14240446 Castle Lake gage. Elev. Elevation; m, meter; NAVD 88, North American Vertical Datum of 1988. 
Table 2. Area/capacity table of Castle Lake, Washington, derived from this study.

[NAVD 88, North American Vertical Datum of 1988; m, meter; $\mathrm{m}^{3}$, cubic meter; km² , square kilometer]

\begin{tabular}{ccc}
\hline $\begin{array}{c}\text { Lake surface elevation } \\
(\mathbf{m} \text { above NAVD 88) }\end{array}$ & $\begin{array}{c}\text { Lake volume } \\
\left(\mathbf{1 0}^{6} \mathbf{~}^{\mathbf{3}}\right)\end{array}$ & $\begin{array}{c}\text { Lake surface area } \\
\left(\mathbf{k m}^{2}\right)\end{array}$ \\
\hline 785.00 & 20.09 & 1.123 \\
785.20 & 20.32 & 1.124 \\
785.40 & 20.54 & 1.125 \\
785.60 & 20.76 & 1.127 \\
785.80 & 20.99 & 1.130 \\
786.00 & 21.22 & 1.133 \\
786.20 & 21.44 & 1.136 \\
786.40 & 21.67 & 1.139 \\
786.60 & 21.90 & 1.143 \\
786.80 & 22.13 & 1.147 \\
787.00 & 22.36 & 1.151 \\
787.20 & 22.59 & 1.155 \\
787.40 & 22.82 & 1.160 \\
787.60 & 23.06 & 1.164 \\
787.80 & 23.29 & 1.168 \\
788.00 & 23.52 & 1.172 \\
788.20 & 23.76 & 1.176 \\
788.40 & 23.99 & 1.180 \\
788.60 & 24.23 & 1.184 \\
788.80 & 24.46 & 1.187 \\
789.00 & 24.70 & 1.191 \\
789.20 & 24.94 & 1.194 \\
789.40 & 25.18 & 1.198 \\
789.60 & 25.42 & 1.201 \\
789.80 & 25.66 & 1.205 \\
790.00 & 25.90 & 1.208 \\
\hline & &
\end{tabular}




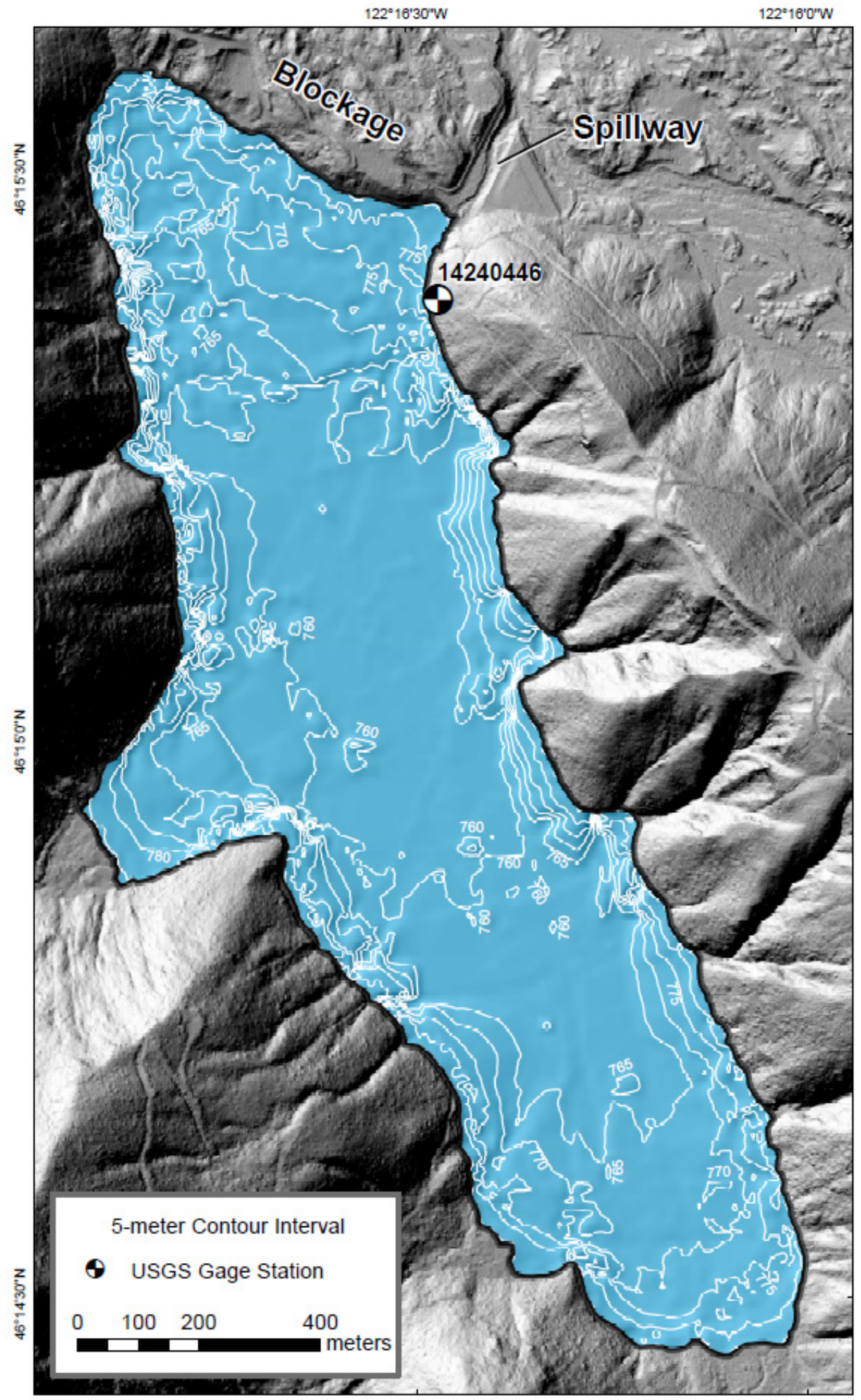

Figure 10. Bathymetric map of Castle Lake, Washington. Base map from Mosbrucker (2014). 


\section{Accuracy Assessment}

Survey precision and accuracy can be quantified for several factors; each step in the data acquisition and processing workflow adds uncertainty to the final products (table 3 ). These include evaluating lake surface elevation, GNSS, lidar, and ADCP measurements. Vertical accuracy is the primary metric to assess topographic and bathymetric elevation models (for example, Federal Geographic Data Committee [FGDC], 1998). As discussed in Wilson and Richards (2006), the largest source of uncertainty is commonly the depth measurement (the ADCP in this case). Because of this, accuracy of other factors is commonly overlooked, or assumed to be within equipment manufacturer's specifications. Here, we discuss each accuracy component, calculate fundamental vertical accuracy from a set of independent physical measurements, and consider how area/capacity information is affected by this uncertainty.

Table 3. Summary of estimated accuracies of each survey component.

[cm, centimeter; GNSS, global navigation satellite system; RTK-GNSS, real-time kinematic global navigation satellite system; ADCP, acoustic Doppler current profiler; DTM, digital terrain model]

\begin{tabular}{lc}
\hline \multicolumn{1}{c}{ Component } & $\begin{array}{c}\text { Vertical uncertainty } \\
\text { (cm) }\end{array}$ \\
\hline Reference monuments & 0.3 \\
Recorded lake elevation & 0.6 \\
GNSS base station solutions & 3.3 \\
RTK-GNSS rover solutions & 1.5 \\
ADCP, temperature & $189^{\mathrm{a}}$ \\
ADCP, roll/pitch & $140^{\mathrm{a}}$ \\
Airborne lidar & 10 \\
Datum transformations & 5.0 \\
Theoretical, depth measurement & $240^{\mathrm{a}, \mathrm{b}}$ \\
Fundamental, final DTM & 72 \\
Fundamental, bathymetric map & 196 \\
\hline
\end{tabular}

${ }^{a}$ Maximum error at greatest depth.

${ }^{\mathrm{b}}$ Root Sum of Squares equation at 95-percent confidence interval.

\section{Lake Surface Elevation}

Water surface elevation at Castle Lake is affected by water temperature, lake seiche, and wind action. Combined with instrumentation and datum transformation errors, these factors can degrade the accuracy of the gage station record. At this station, lake surface elevation values have an accuracy of $0.01 \mathrm{~m}$ ( $0.03 \mathrm{feet})$ based on third-order reference marks established using an engineering level with 0.0003-m (0.001 feet) precision (Kenney, 2010; Sauer and Turnipseed, 2010). Recorded elevation values (0.003-m precision) at the USGS gage varied by only $0.006 \mathrm{~m}$ over the 3-day bathymetric survey so elevation was treated as fixed during processing. 


\section{GNSS Position Solutions}

GNSS positioning is subject to a wide variety of complex factors; readers are referred to a summary available in Rydlund and Densmore (2012). GNSS solution quality was evaluated by blunder checks, software algorithms, and daily comparisons to survey monuments. Survey monuments provided vertical control only; horizontal accuracy could not be independently tested. Almost 96 percent of GNSS rover solutions were RTK-corrected at the time of acquisition. All GNSS data collection and processing strictly adhered to quality control practices described in Rydlund and Densmore (2012). Quality control RTK-GNSS observations were made with the rover on two USGS gage station reference points (RP1 and RP3) and two USACE survey monuments (CLM-6 and CLM-7). In addition to these standard techniques, quality control observations were compared to third-order level circuits conducted by the USGS in 1995 and 2012. Six RTK-GNSS observations of RP1 and RP3 were all less than $1.5 \mathrm{~cm}$ (mean of 0.7 $\mathrm{cm}$ ) different in the vertical than the August 16, 2012, level circuit, which had a closure error of less than $0.03 \mathrm{~cm}$. Six RTK-GNSS observations of CLM- 6 and CLM-7 were all less than $2.9 \mathrm{~cm}$ (mean of $0.00 \mathrm{~cm}$ ) different than the October 18, 1991, level circuit, which had a closure error of $6.1 \mathrm{~cm}$. Accuracy of the base station network solution is $0.4 \mathrm{~cm}$ horizontal and $3.3 \mathrm{~cm}$ vertical root-mean-square-error (RMSE) at the 95-percent confidence interval. Given these measures, the overall quality of RTK-GNSS rover solutions are considered Level II, whereas the base stations are Level I (per Rydlund and Densmore, 2012).

\section{Lidar Topographic Points}

Airborne laser scanning, or lidar, is an established method to produce high-resolution and high-precision topographic data. Accuracy of DTMs derived from lidar is affected by several factors, such as ground sample distance, point density, systematic and random errors in laser point solutions, quality of control data, extraction of ground returns, and surface interpolation method (for example, Passalacqua and others, 2015). For the lidar dataset, absolute vertical accuracy is stated as $10 \mathrm{~cm}$ at the 95-percent confidence interval on bare road surfaces and found to be as great as $50 \mathrm{~cm}$ in vegetated areas (Mosbrucker, 2014). RTK-GNSS rover solutions taken on CLM-6 and CLM-7 benchmarks have greater residuals owing to heavy tree canopy cover which can also affect the accuracy of GNSS solutions. For this study, less than 5 percent of the surface area at the maximum modeled stage of $790 \mathrm{~m}$ (that is, the spatial boundary extent of the bathymetric model) has heavy tree canopy cover.

\section{ADCP Depth Measurements}

The ADCP used to acquired depth soundings is designed to measure surface water discharge in volume per time (for example, cubic meters per second) from velocity and crosssectional area measurements. Discharge measurement accuracy is typically $2-5$ percent for ideal conditions (that is, rivers with $<10$-m depth, low turbidity, and laminar flow). When used for bathymetric surveying, this instrument has greater potential error than a survey-grade echo sounder. This is partially due to lower quality thermistors and inertial measurement units.

The speed of sound in water is associated with water temperature and salinity; these parameters can have a significant effect on depth measurements. The ADCP measures water temperature at the transducer only (thermistor stated $\pm 0.4^{\circ} \mathrm{C}$ accuracy and $\pm 0.01{ }^{\circ} \mathrm{C}$ precision; Teledyne RD Instruments, 2007) and water-depth measurements are not compensated for variations with depth. Given uniform salinity and temperature through the water column, depth 
measurements are stated as \pm 1 percent (Teledyne RD Instruments, 2007). At the maximum measured depth of $29.78 \mathrm{~m}$, this reflects an uncertainty less than $30 \mathrm{~cm}$. Conductivity is used as an indirect measurement of salinity. To evaluate this uncertainty, independent water temperature and conductivity profiles are measured in six locations (fig. 8) using a Schlumberger CTD-Diver (conductivity, temperature, and depth diver) calibrated to National Institute of Science and Technology (NIST) standards.

Profile data show conductivity ranges from 0.000 to 0.046 millisiemens per centimeter $(\mathrm{mS} / \mathrm{cm})$ with a mean of $0.002 \mathrm{mS} / \mathrm{cm}$. When converted to salinity using temperature (measured) and pressure (inferred by observation depth), values are uniform through the water column. However, temperature values are found to be non-uniform. During our survey, near-surface temperature at the transducer ranged from 19.51 to $22.75^{\circ} \mathrm{C}$ with a mean of $21.28{ }^{\circ} \mathrm{C}$; the nearsurface profile data average is less than 1 percent different than the ADCP thermistor. At the deepest parts of the lake, average water temperature is $5.38{ }^{\circ} \mathrm{C}$. This $15.90{ }^{\circ} \mathrm{C}$ difference is found to be linear. Without compensating for lower temperatures near the lake bed, water-depth measurements are conservatively estimated to be biased 2 percent less than actual depth per $5-{ }^{\circ} \mathrm{C}$ temperature error (Mueller and Wagner, 2009). At the maximum measured depth of $29.78 \mathrm{~m}$ (based on water temperature measured at the surface), a 2 percent error per $5{ }^{\circ} \mathrm{C}$ suggests an actual depth of $31.67 \mathrm{~m}$ (1.89 $\mathrm{m}$ or 6.35 percent greater than recorded by the ADCP).

An inertial measurement unit integrated into the ADCP provides roll and pitch values for each corresponding depth measurement (stated $\pm 0.5^{\circ}$ accuracy and $\pm 0.01^{\circ}$ precision; Teledyne RD Instruments, 2007). Recorded pitch values range from $-9.46^{\circ}$ to $6.74^{\circ}$ with a mean of $0.16^{\circ}$. Recorded roll values range from $-5.02^{\circ}$ to $5.32^{\circ}$ with a mean of $-1.26^{\circ}$. Based on geometry, the largest errors introduced by roll and pitch are located at the deepest parts of the lake. At a water depth of $30 \mathrm{~m}$, roll and pitch uncertainties can account for as much as $1.40 \mathrm{~m}$ negative vertical bias (4.7 percent less depth than recorded by the ADCP).

\section{Accuracy of Bathymetric Map and Area/Capacity Table}

Accuracy of area/capacity computations derived from geospatial data analyses are dependent on the quality of the source DTM. Topographic, or bathymetric, point density is a primary factor controlling DTM accuracy. Wilson and Richards (2006) find a 3-14 percent average reduction in computed volume at transect intervals less than $120 \mathrm{~m}$ and a 36 percent average negative bias between 120 and $240 \mathrm{~m}$ intervals. Transect intervals for our survey are generally 60-150 m, producing 190,827 depth measurements (after filtering out 12 percent of the recorded points owing to the shallow water blanking distance of the ADCP and the removal of submerged trees that interfered with the surface model). Although airborne lidar data had relatively regular point spacing, 40 percent of the bathymetric survey area had less than one point per 100 square meters. In areas of low topographic relief and roughness, simple interpolation algorithms are appropriate, but relatively low point density (that is, large transect intervals) and non-survey grade depth measurements caused our survey to be less accurate than bathymetric surveys conducted on similarly sized lakes (Wilson and Richards, 2006).

We consider theoretical and fundamental accuracy of the products separately. Theoretical accuracy, estimated using simple error propagation through the root sum of squares equation (RSS) (for example, Bevington, 1969; Brasington and others, 2003), is based on manufacturer specifications such as measurement precision and stated accuracies determined by instrument tests under ideal conditions (table 3). Considering each component, theoretical vertical accuracy of water-depth measurements is $2.40 \mathrm{~m}$ at the 95-percent confidence interval. 
Fundamental vertical accuracy is determined by comparing bathymetric surface values (from the final DTM) to six independent depth soundings using a weighted tagline (fig. 8), which we assume has greater accuracy than ADCP-measured depths (FGDC, 1998). Sounding depth ranges from 1.71 to $28.16 \mathrm{~m}$. We compute mean absolute error (MAE) and RMSE from these residuals (for example, Greenwalt and Schultz, 1968; Mosbrucker and others, 2016). MAE is an equally weighted (linear) measurement of error, whereas RMSE measures the average magnitude of error using a quadratic function that is more sensitive to large values. Our results show a large difference between the two owing to a large degree of variance within error residuals (RMSE is 5.6 times greater than MAE). Based on MAE, the fundamental vertical accuracy of the final DTM, from which the area/capacity table is computed from, is found to be $0.72 \mathrm{~m}$. This uncertainty represents 0.88 million $\mathrm{m}^{3}$ (4.1 percent of the total volume). Using these same check points, the bathymetric map derived from spline interpolation tested to have 1.96-m fundamental vertical accuracy (which would represent 2.41 million $\mathrm{m}^{3}$, or 11.2 percent of the total volume, had it been used to compute the area/capacity table instead of the final DTM).

Relationships developed by our results provide a conversion between historical datums and modern orthometric height; we found the elevation of the TVGT datum of 1981 to be $1.43 \mathrm{~m}$ lower than NAVD 88 (by GEOID12A) at Castle Lake (table 4). Relationships also provide a means to compute lake volume from near real-time lake elevation measurements (USGS station 14240446 Castle Lake) or by measuring lake surface area from remotely sensed imagery.

Table 4. Comparison between lake surface elevation found in this study and that published by Wiggins and others (1995) for a given lake volume.

[Mean elevation difference is 23.46 m. NAVD 88, North American Vertical Datum of 1988; m, meter; m³, cubic meter]

\begin{tabular}{ccc}
\hline $\begin{array}{c}\text { Lake volume } \\
\left(\mathbf{1 0 ^ { 6 }} \mathbf{~ m}^{\mathbf{3}}\right)\end{array}$ & $\begin{array}{c}\text { Elevation, this study } \\
\text { (m above NAVD } \mathbf{8 8})\end{array}$ & $\begin{array}{c}\text { Elevation, Wiggins (1995) } \\
\text { (m above arbitrary) }\end{array}$ \\
\hline 22.49 & 787.11 & 810.46 \\
22.82 & 787.40 & 810.77 \\
23.16 & 787.69 & 811.07 \\
23.51 & 787.51 & 811.38 \\
23.86 & 788.29 & 811.68 \\
24.20 & 788.58 & 811.99 \\
24.55 & 788.87 & 812.29 \\
24.89 & 789.16 & 812.60 \\
25.24 & 789.45 & 812.90 \\
25.58 & 789.73 & 813.21 \\
25.93 & 790.02 & 813.51 \\
26.27 & 790.31 & 813.82 \\
\hline
\end{tabular}

\section{Summary}

Castle Lake was impounded by a massive debris avalanche produced during the May 18, 1980, eruption of Mount St. Helens. Risk of the blockage failing was partially mitigated by the construction of an emergency spillway in late 1981 to stabilize lake surface elevation. The blockage is thought to be marginally stable except under certain conditions (for example, extreme hydrologic event or large earthquake). Early mapping efforts proved adequate to support 
several lake breakout models, but relatively large uncertainty associated with horizontal and vertical datums prevented previous capacity (volume) tables from being useful to current lake monitoring and hazard assessment efforts.

This paper presented the results of a bathymetric survey conducted in August 2012 (Mosbrucker and Spicer, 2017). We documented data acquisition, processing, integration, and accuracy. A survey-grade global navigation satellite system (GNSS) was used to position an acoustic Doppler current profiler (ADCP) that measured water depth. More than 191,000 waterdepth measurements (1.71-28.16 meters [m]) were integrated with high-resolution airborne lidar data acquired in September 2009 to compute the full range of values needed to relate lake elevation to area and capacity.

For period-of-record lake elevations between 785.8 and $787.2 \mathrm{~m}$, volume computed from our survey ranges from 21.0 to $22.6 \pm 0.88$ million cubic meters $\left(\mathrm{m}^{3}\right)$; associated lake surface area ranges from 1.13 to 1.16 square kilometers $\left(\mathrm{km}^{2}\right)$. Fundamental vertical accuracy of our digital terrain model (DTM) derived from depth soundings $(0.72 \mathrm{~m})$ is better than the theoretical accuracy $(2.40 \mathrm{~m})$ of our survey instrument system, despite relatively large transect spacing.

Lake volume derived from our survey generally confirms values published in earlier studies of blockage stability and dam-break flood modeling. Compared to these studies, which use (or reference) bathymetric contours developed from a 1981 survey, our volume is 3.8-7.9 percent less and surface area is 5.8-38.9 percent less for period-of-record lake elevations. Dambreak modeling efforts used an initial volume $\left(23\right.$ million $\left.\mathrm{m}^{3}\right)$ greater than we calculate for the period-of-record maximum surface elevation; we found this volume corresponds to a lake surface elevation $0.36 \mathrm{~m}$ higher than the maximum recorded.

\section{Acknowledgments}

We thank Jonathan Czuba, Virginia Tech, for his technical assistance and manuscript review; Pete Emerson, J.L. Aviation, for his field assistance; and Tami Christianson and Joseph Bard, U.S. Geological Survey, for their technical reviews.

\section{References Cited}

Bevington, P.R., 1969, Data reduction and error analysis for the physical sciences: New York, McGraw-Hill, 336 p.

Brasington, J., Langham, J., and Rumsby, B., 2003, Methodological sensitivity of morphometric estimates of coarse fluvial sediment transport: Geomorphology, v. 53, p. 299-316.

Czuba, J.A., Olsen, T.D., Czuba, C.R., Magirl, C.S., and Gish, C.C., 2012, Changes in sediment volume in Alder Lake, Nisqually River basin, Washington, 1945-2011: U.S. Geological Survey Open-File Report 2012-1068, 30 p.

Denlinger, R.P., 2012, Effects of catastrophic floods and debris flows on the sediment retention structure, North Fork Toutle River, Washington: U.S. Geological Survey Open-File Report 2011-1317, 25 p.

Embrey, S.S., and Dion, N.P., 1988, Effects of the 1980 eruption of Mount St. Helens on the limnological characteristics of selected lakes in western Washington: U.S. Geological Survey Water-Resources Investigations Report 87-4263, 60 p.

Federal Geographic Data Committee, 1998, Geospatial positioning accuracy standards, Part 3National standard for spatial data accuracy: National Spatial Data Infrastructure FDGC-STD007.3-1998, 25 p. 
Greenwalt, C.R., and Schultz, M.E., 1968, Principles of error theory and cartographic applications: U.S. Air Force Aeronautical Chart and Information Center Technical Report No. 96, 98 p.

Kenny, T.A., 2010, Levels at gaging stations: U.S. Geological Survey Techniques and Methods, book 3, chap. A19, 60 p.

Laenen, A., and Orzol, L.L., 1987, Flood hazards along the Toutle and Cowlitz Rivers, Washington, from a hypothetical failure of Castle Lake blockage: U.S. Geological Survey Water-Resources Investigations Report 87-4055, 34 p.

Li, Z., Zhu, Q., and Gold, C., 2005, Digital terrain modeling-principles and methodology: Boca Raton, CRC Press, 323 p.

Lipman, P.W., and Mullineaux, D.R., eds., 1981, The 1980 eruption of Mount St. Helens, Washington: U.S. Geological Survey Professional Paper 1250, 844 p.

McKnight, D.M., Klein, J.M., and Wissmar, R.C., 1984, Changes in the organic material in lakes in the blast zone of Mount St. Helens, Washington: U.S. Geological Survey Circular 850-L, $26 \mathrm{p}$.

Meyer, W., and Sabol, M., 1989, Hydrology of the Castle Lake blockage, Mount St. Helens, Washington: U.S. Geological Survey Water-Resources Investigations Report 87-4272, 29 p.

Meyer, W., Sabol, M.A., Glicken, H.X., and Voight, B., 1985, The effects of ground water, slope stability, and seismic hazards on the stability of the South Fork Castle Creek blockage in the Mount St. Helens area, Washington: U.S. Geological Survey Professional Paper 1345, 42 p.

Meyer, W., Schuster, R.L., and Sabol, M.A., 1994, Potential for seepage erosion of landslide dam: Journal of Geotechnical Engineering, v. 120, no. 7, p. 1211-1229.

Mosbrucker, A.R., 2014, High-resolution digital elevation model of Mount St. Helens crater and upper North Fork Toutle River basin, Washington, based on an airborne lidar survey of September 2009: U.S. Geological Survey Data Series 904, https://doi.org/10.3133/ds904.

Mosbrucker, A.R., Major, J.J., Spicer, K.R., and Pitlick, J., 2016, Camera system considerations for geomorphic applications of SfM photogrammetry: Earth Surface Processes and Landforms, vol. 42, no. 6, p. 969-986, https://doi.org/10.1002/esp.4066.

Mosbrucker, A.R., and Spicer, K.R., 2017, Bathymetric dataset for Castle Lake, Mount St. Helens, Washington, from survey on August 1-3, 2012: U.S. Geological Survey Data Release, https://doi.org/10.5066/F71835CT.

Mosbrucker, A.R., Spicer, K.R., Major, J.J., Saunders, D.R., Christianson, T.S., and Kingsbury, C.G., 2015, Digital database of channel cross-section surveys, Mount St. Helens, Washington: U.S. Geological Survey Data Series 951, 9 p. and supplemental data, https://doi.org/10.3133/ds951.

Mueller, D.S., and Wagner, C.R., 2009, Measuring discharge with acoustic Doppler current profilers from a moving boat: U.S. Geological Survey Techniques and Methods, book 3, chap. A22, $72 \mathrm{p}$.

National Geodetic Survey, 2011, GEOID03: National Geodetic Survey website, accessed October 15, 2012, at https://www.ngs.noaa.gov/GEOID/GEOID03/.

National Geodetic Survey, 2012a, GEOID12A: National Geodetic Survey website, accessed October 15, 2012, at https://www.ngs.noaa.gov/GEOID/GEOID12A/.

National Geodetic Survey, 2012b, Geodetic Toolkit: XYZ Conversion: National Geodetic Survey website, accessed December 14, 2012, at https://www.ngs.noaa.gov/TOOLS/XYZ/xyz.shtml. 
National Geodetic Survey, 2012c, OPUS Projects: National Geodetic Survey website, accessed December 14, 2012, at http://www.ngs.noaa.gov/OPUSI/OpusProjects.html.

Passalacqua, P., Belmont, P., Staley, D.M., Simley, J.D., Arrowsmith, J.R., Bode, C.A., Crosby, C., DeLong, S.B., Glenn, N.F., Kelly, S.A., Lague, D., Sangireddy, H., Schaffrath, K., Tarboton, D.G., Wasklewicz, T., and Wheaton, J.M., 2015, Analyzing high resolution topography for advancing the understanding of mass and energy transfer through landscapesA review: Earth-Science Reviews, v. 148, p. 174-193.

Roeloffs, E.A., 1994, An updated numerical simulation of the ground-water flow system for the Castle Lake debris dam, Mount St. Helens, Washington, and implications for dam stability against heave: U.S. Geological Survey Water-Resources Investigations Report 94-4075, 92 p.

Rydlund, P.H., and Densmore, B.K., 2012, Methods of practice and guidelines for using surveygrade global navigation satellite systems (GNSS) to establish vertical datum in the United States Geological Survey: U.S. Geological Survey Techniques and Methods, book 11, chap. D1, $102 \mathrm{p}$.

Sauer, V.B., and Turnipseed, D.P., 2010, Stage measurement at gaging stations: U.S. Geological Survey Techniques and Methods, book 3, chap. A7, 45 p.

Teledyne RD Instruments, 2007, WorkHorse Rio Grande Acoustic Doppler Current Profiler: Technical Manual 957-6241-00, 264 p.

U.S. Army Corps of Engineers, 1988, Castle Lake-Engineering analysis and alternative evaluation: U.S. Army Corps of Engineers, Portland District, 80 p.

U.S. Army Corps of Engineers, 1990, Numerical simulation of mudflows from hypothetical failures of the Castle Lake debris blockage near Mount St. Helens, WA: U.S. Army Corps of Engineers, Hydrologic Engineering Center, Final Project Report No. 90-05, 102 p.

U.S. Army Corps of Engineers, 1992, Castle Lake-Criteria and performance report: U.S. Army Corps of Engineers, Portland District, Planning and Engineering Division, $101 \mathrm{p}$.

U.S. Department of Agriculture, 2011, National Agriculture Imagery Program: U.S. Department of Agriculture website, accessed October 6, 2011, at http://www.fsa.usda.gov/programs-andservices/aerial-photography/imagery-products/index.

U.S. Geological Survey, 1980, View northwest across the new Castle Creek Lake, northwest of Mount St. Helens, Skamania County, Washington, June 11, 1980: USGS Denver Library Photographic Collection, ID mkhh0003.

U.S. Geological Survey, 2013, Water-resources data for the United States, Water Year 2012: U.S. Geological Survey Water-Data Report WDR-US-2012, site 14240446, accessed at http://wdr.water.usgs.gov/wy2012/pdfs/14240446.2012.pdf.

Wiggins, W.D., Ruppert, G.P., Smith, L.L., Reed, L.L., Hubbard, L.E., and Courts, M.L., 1995, Water resources data, Washington, water year 1994: U.S. Geological Survey Water-Data Report WA-94-1, site 14240446, p. 428.

Wiggins, W.D., Ruppert, G.P., Smith, L.L., Reed, L.L., Hubbard, L.E., and Courts, M.L., 1996, Water resources data, Washington, water year 1995: U.S. Geological Survey Water-Data Report WA-95-1, site 14240446, p. 437-438.

Wilson, G.L., and Richards, J.M., 2006, Procedural documentation and accuracy assessment of bathymetric maps and area/capacity tables for small reservoirs: U.S. Geological Survey Scientific Investigations Report 2006-5208, 24 p. 
Manuscript approved on November 7, 2017

For more information about this publication, contact

Director

Volcano Science Center, Cascades Volcano Observatory

U.S. Geological Survey

1300 SE Cardinal Court, Building 10, Ste. 100

Vancouver, WA 98683-9589

Publishing support provided by the

Menlo Park Publishing Service Center 